\title{
BOOK REVIEW: Reggaeton
}

\section{Transforming Cultures eJournal, \\ Vol. 4 No 1 April 2009 http://epress.lib.uts.edu.au/journals/TfC}

\begin{abstract}
Reggaeton edited by Raquel Z. Rivera, Wayne Marshall and Deborah Pacini Hernandez, Durham NC, Duke University Press, 2009. 392 Pages. ISBN: 978-08223-4383-7.
\end{abstract}

\section{Cameron White}

Reggaeton is a contemporary music genre with an associated dance form (perrero). It has its roots in an early 1990s fusion of Jamaican dancehall rhythms (riddims), African American hip hop rhythms and Spanish lyrics. In 2004-05 reggaeton emerged from the underground to become the most marketable Latin music genre of its era. This shift was marked by the chart-climbing success of performers such as Daddy Yankee, Don Omar and Tego Calderon.

The story of reggaeton is understood as an expression of a twentieth century history of circular migration and movement throughout the Caribbean and between the Caribbean and the United States, especially New York. Thus Jamaica, Panama, Puerto Rico and New York can all be considered as the birthplace of reggaeton. The transnational complexity of reggaeton is such that, in the words of Juan Flores it can be considered to be:

the first transnational music in the full sense of the term... without any single specifiable place of origin, with no can (cradle) in the sense of a 'hood' or even national setting from which it sprang (p. x).

The "burgeoning number" of competing histories of reggaeton illustrate the extent to which the genre's transnationalism challenges master narratives about national identities (p. 135). The editors of this volume are well positioned to confront the challenges posed by their subject. Previously they have each made important contributions towards understanding the impact of Caribbean music and Caribbean migration on American popular music. Raquel Z. Rivera's articles on hip hop have been instrumental in foregrounding the impact of Puerto Ricans on the genre. Wayne Marshall has written extensively about the interplay between reggae and hip hop in a number of scholarly 
articles. His blog wayneandwax.com is also an excellent and up to date source on the subject. Deborah Pacini Hernandez has written many articles on Spanish Caribbean and U.S. Latino popular music and recently co-edited a book on rock in Latin/o America".

Many of the essays in the first half of Reggaeton are concerned with the task of clarifying the reggaeton story. Wayne Marshall argues that reggaeton emerged in Puerto Rico in the early 1990s as a rich, locally inflected interpretation of the confluence of rap and reggae taking place in New York at that time. For Marshall, it is in the triangular movement of people, ideas and music between Jamaica, New York and Puerto Rico that we can begin to understand the origins of reggaeton. Other essays place Panama at the centre of 'the reggaeton narrative' by looking at the emergence of a form of Jamaican dancehall reggae with Spanish lyrics (reggae en español) in that country. Deborah Pacini Hernandez, on the other hand, looks at the influence of Dominicans in reggaeton. She argues:

Historic tensions between Puerto Ricans and Dominicans have muted the visibility of Dominicans in public discourse about reggaeton in a similar way that Puerto Ricans themselves were elided from histories of hip hop (p. 157).

In addition to examining its genealogy, the book also considers the political significance of reggaeton. During the formative years of the genre, as Wayne Marshall and others argue, reggaeton was marked by a firm and empowering emphasis on Blackness which reflected the influence of reggae and hip hop. More recently, however, following the international success of reggaeton artists in the mid-2000s, reggaeton has been threatened by a vapid, sexist, polysemous commercialism. As influential reggaeton producer Boy Wonder has suggested; 'Every kind of message can be said with this music... and you can put a face on any product' (p. 59).

The book presents a number of different responses to this view of contemporary reggaeton. Geoff Baker, writing about reggaeton in the Cuban context argues that its significance emerges as a function of (rather than in spite of) its body-centered hedonism and emphasis on individualism. "[Reggaeton's] focus on self-indulgence and pleasure", he writes", is implicitly a form of liberation from the official, politicised national culture [of socialist ideology, collectivity and self-sacrifice]” (p. 193). 
One of the most interesting themes in the book explores the way reggaeton has challenged the hegemony of English speaking hip hop amongst Latino youth throughout the U.S. and the Caribbean. In his chapter on "the Miami urban scene" Jose Davila describes the way Miami Latinos celebrated reggaeton as una cosa latina [a Latin thing]. Reggaeton gave Latinos a voice, a (musical) history and an identity which had been elided by the powerful influence of rap.

Nieves Moreno suggests that this "return" to the people" also had a gendered dimension. While many commentators have accused reggaeton of purveying sexist imagery (including Jan Fairley in this volume), Nieves Moreno suggests that at least some of this imagery has been inherited from hip hop. Moreover, he argues that reggaeton has actually provided opportunities to upset normative gendered identities. The possibility of a gendered critique has been exemplified by the Puerto Rican group Calle 13, who persistently poke fun at the "manly" man depicted in most reggaeton imagery. Similarly, Félix Jiméniz and Alexandra T. Vazquez both look at the way in which reggaeton artist Ivy Queen "disrupt[s] secure assumptions of penetration" (p. 302) by "structur[ing] her career with a gender difference [firmly] in mind" (p. 239).

In addition to looking at how reggaeton itself can critique (and/or reinforce) metanarratives of class, race and gender, the book also introduces a focus on the genre's reception (as opposed to its production). In the hands of Alexandra T. Vazquez, this emphasis on reception takes us into many unexpected worlds, including the beauty salon, where she examines the agency of women as they prepare for their encounter with reggaeton at a club or concert

In conclusion, Reggaeton is an excellent collection which itself occasions many surprises. Overall the book is structured in much the same way as its subject (reggaeton), as a series of overlapping, interconnected and often contradictory layers. In addition to "mapping" the transnational genealogy of reggaeton, the book also outlines a series of thematic approaches. As well as reading reggaeton's racial politics, the politics of class and gender are also considered. The consumption of reggaeton is considered as well as its production. Reggaeton artists, poets, filmmakers, photographers and journalists discuss their views alongside academics. Finally, and perhaps most importantly, the collection is a transnational one and includes a number of essays which 
have been translated from the Spanish (and also German) as well as a number of essays by scholars based in Latin America. This book is a tour de force of criticism and analysis which is relevant not only to the study of reggaeton but to the study of popular music in general. 